\title{
Finding the Technological Sweet Spot: The Smallholder Conservation Agriculture Maize Seeder
}

\author{
Rebecca M. Harman ${ }^{1}$, Neal S. Eash ${ }^{1}$, John E. Morrison Jr. (deceased) ${ }^{1}$, William E. Hart ${ }^{1}$, Casey T. Sullivan ${ }^{1}$ \& \\ Dayton M. Lambert ${ }^{2}$ \\ ${ }^{1}$ Biosystems Engineering and Soil Science, University of Tennessee, Knoxville, Tennessee, USA \\ ${ }^{2}$ Agricultural and Resource Economics, University of Tennessee, Knoxville, Tennessee, USA \\ Correspondence: Rebecca Harman, Biosystems Engineering and Soil Science, University of Tennessee, 2506 E.J. \\ Chapman Dr., Knoxville, TN 37996, USA. Tel: 1-615-473-0332. E-mail: rebeccamattinglyharman@gmail.com
}

Received: March 20, 2017 Accepted: July 17, $2017 \quad$ Online Published: September 29, 2017

doi:10.5539/jsd.v10n5p241 URL: https://doi.org/10.5539/jsd.v10n5p241

\begin{abstract}
The seeder is integral to smallholder agricultural production. This technology seeks to lessen farmer labor requirements, meter seeds accurately, and minimize excessive soil disturbance. Hand seeders play a central role in conservation agriculture (CA) for the smallholder farmer as a means to plant through residue cover and penetrate non-tilled soil surfaces. Two trials in maize (Zea mays, L.) residue and soybean (Glycine max, L.) residue were conducted to test seven seeders of increasing mechanization levels: five hand operated, one mechanized, and one tractor-drawn control. The experiment site was in Mt. Gilead, Ohio, at the Eastern end of the US "Corn Belt" that had been under continuous no-till production for seven years. Experimental conditions at the site sought to mimic smallholder conditions through seeding and hand harvesting. Seeders were evaluated based on plant population establishment, crop growth stage, crop heights and final maize grain yield. The hand seeders were further evaluated based on their economic viability and usability - key challenges to the ultimate adoption of new seeding technologies. The study found that the seeders tested performed equally to the control, the John Deere MaxEmerge Conservation planter, the crop-seeding capacity and price evaluation identified the Haraka rolling planter ill-suited for smallholders while the OSU Greenseeder proved highest qualitative performance. In conclusion, all evaluations indicate that a medium level of mechanization is appropriate and necessary to be successful in a smallholder CA system although continued research is necessary.
\end{abstract}

Keywords: conservation agriculture, maize seeders, smallholder agriculture

\section{Introduction}

\subsection{Smallholder Agriculture Challenges and Needs}

Smallholder farmers - those who farm 2 ha of land or less - produce more than $70 \%$ of the world's food (Wolfenson et al., 2013), and are charged to increase food production by $70 \%$ to supply the projected 9.2 billion population in 2050 (Bruinsma, 2003). To sustain the smallholder sector, loss of soil fertility and increasing soil erosion must be addressed - the CA model seeks to improve these soil conditions in agriculture. The defining concepts of $\mathrm{CA}$ - maintaining crop residues, minimally disturbing the soil surface and intercropping and/or crop rotation - are particularly impactful in the developing world (Thierfelder et al., 2009).

Central to the adoption and success of CA in smallholder agriculture is an effective seeding tool—one that can be used successfully to plant seed at consistent depths and establish full crop stands even when used in soils with high amounts of protective residue coverage. Although CA eliminates the need for heavy land preparation, the task of seeding through residues on hard soils is arduous for the operator and made either more or less difficult depending on the tool employed (Kienzle, 2014). A CA system for a smallholder necessitates seeding equipment that is durable and reliable, is an economical investment, and should complement current practices, gender roles, cultural precedence and, to be sure, achieve yields commensurate with the level of inputs.

Hand implements are predominantly used in developing countries for many agricultural tasks-typically either short handled, requiring extensive labor for seeding, tillage, and weeding. Although modern mechanization of agriculture has counterbalanced the need for manual work in some sectors, agriculture for smallholder farmers remains as mostly manual labor with excessive drudgery (Vanderwal et al., 2011; Fathallah et al., 2008). Out of 
the 160 million ha of maize grown in 2009, 34 million ha were grown in the developing world, of which $60 \%$ was planted by hand (FAO, 2010). In total, 13\% of total maize grown in the world is seeded by hand. Human power remains the primary means of agricultural production in the world with $59 \%$ of agricultural production accomplished completely without animal or engine power in Latin America and 89\% in Africa (Comsec, 1990). Despite significant efforts to increase mechanization in developing countries, human powered tools remain the predominant means of work. Manual tools constitute the most common mechanization level for smallholder farmers, especially in sub-Saharan Africa (SSA) (Africa, 2013); continued investment in hand-tool technology is critical to improving sustainable intensification among smallholder farmers in maize production.

\subsection{Challenges to Smallholder CA Technology}

Achieving global food security from local agricultural production demands much of smallholder farmers. Under the increasing pressures of growing populations and an exceedingly unpredictable climate, smallholder farmers of the developing world face low and declining yields, soil degradation, unsustainable soil and crop management methods and erratic weather patterns (Csaki and deHaan, 2003). These challenges characterize the 500 million smallholder farms from SSA, Central and South America and South and Southeast Asia. These farmers feed more than 2 billion people (IFAD, 2013).

The majority of smallholder agriculture takes place in regions of the world deemed "less developed," in the sub-humid and tropical climates where soils are inherently less fertile and food production is generally more challenging. These regions include SSA, South and Southeast Asia, Central America and the Caribbean and areas of South America. Adding further complexity to projected food needs, the per capita availability of agricultural land is diminishing, soil fertility is being depleted, the climate is warming and weather systems are increasingly erratic (Altieri et al., 2008; Friedrich et al., 2009; Sanchez et al, 1997).

Throughout the developing world, women are largely responsible for seeding crops, as well as preparing the seed bed and harvesting (FAO, 2011). Therefore, for a CA system to be implemented realistically, tools must be designed that suit the women using them and that are sensitive to the cultural and gender dynamics. Identifying suitable seeding technology for women growers or any smallholder is about "appropriate mechanization," or improved technologies that are balanced with economic feasibility, usability and cultural or community acceptance (Mrema, 2008; Baudron, 2015). Reducing labor hours and energy expenditure is crucial to improving the livelihoods of smallholder growers, especially for women growers. Women make up about $43 \%$ of the agricultural labor force in developing countries and, in SSA and eastern and southeastern Asia up to 50\% (FAO, 2012). Gupta (2009) states that women are responsible for seeding approximately 60 to $80 \%$ of food crops in developing countries as well as land preparation, seeding and weeding.

Improving grain yields for the developing world necessitates a focus on manually seeded maize and hand-tool technology (Note 1). The performance of hand seeders -based on yield, effective field capacity and usability depends on a variety of factors including soil, residue, and seeder characteristics, as well as the cost of seeder importation and maintenance (FAO, Tools, Machinery and Equipment, 2015). Each of these factors varies substantially from region to region and between farmers, making the identification of one hand seeder for non-plowed field conditions of CA challenging. Even in the US "Corn Belt", many CA farmers use similar mechanized planters but employ a variety of attachments from smaller companies to improve performance based on their specific needs.

For smallholder farmers, these tools have the potential to lessen labor requirements, improve the effective field capacity of agricultural tasks, improve crop yields with more consistent seeding depth and spacing - all tasks necessary to implement a CA system. As such, the ease of use, learning, and general repair of a planter-the usability- is of high priority to a smallholder farmer. The success of a planter must therefore include a focus not only on expected crop yields, but also comfort and effective use, maintenance, and seeder affordability. A multi-dimensional study is necessary to evaluate new seeding technologies for a CA smallholder system. This study is an attempt to provide data outlining the need and opportunities for smallholder farmers to obtain affordable and effective equipment that can assist in reducing labor needed for family sustenance.

To improve the outlook of smallholder agriculture and achieve sustainability with a CA model, appropriate seeders are necessary. No one seeder can be a panacea to implementing CA in every corner of the developing world. Until the time when such equipment is developed, researchers must evaluate current models available to smallholders, governments and non-governmental organizations (NGO) in the hopes of an improved understanding of the suitability and reliability of available tools and promote only appropriate, affordable, reliable tools. The purpose of this study is 1. Evaluate seeders on plant population establishment, their impact on early growth as measured by crop growth stage heights and final maize grain yield, 2. Evaluate hand seeders 
based on their market price, crop seeding capacity and usability by the operator.

\section{Materials and Methods}

\subsection{Seeder Field Study and Data}

\subsubsection{Experimental Site and Design}

The experimental area was a privately owned farm in Mt. Gilead, Ohio $\left(40^{\circ} 36^{\prime} 18^{\prime \prime} \mathrm{N} 82^{\circ} 40^{\prime} 32^{\prime \prime} \mathrm{W}\right)$. The climate of the area is considered a humid, continental, mild summer and wet throughout the year (Dfb according to Köppen-Geiger, Kottek et al., 2006).

Two separate trials with different crop residues were designed to allow for replication over residue types, namely maize and soybean (Sonnefeld, 2008; Mahmood et al., 2008; Thiagalingam et al., 1991; Migliorati et al., 2014; Du et al., 2004). The soil types were a Condit silt loam (Aquic Hapludalf) and a Bennington silt loam (Aquic Hapludalf) in the maize and soybean residue trials, respectively. The farm has been under a CA system maintained crop residues, and seven years of no-till under a maize-soybean rotation. In the maize residue trial, one-year-old maize residue was present. In the soybean residue trial, two-year-old maize residue and one-year-old soybean residue were present.

The experimental design of each trial was a completely randomized design (CRD) with seven seeder treatments and four replications. The seeders used for this study were chosen to represent levels of seeding mechanization from the most basic to the modern commercial seeders, and to represent a cultural comparison of seeding designs as the come from different regions of the world. The seeders tested were a dibble stick (Eash Farms, Mt. Gilead, USA), OSU Greenseeder (Oklahoma State University, Stillwater, USA), Li Seeder (Yunfan machinery manufacturing Co., LTD, Fushun, China), Brazilian Jab (Fitarelli, Aratiba, Brazil), Haraka rolling (Eden Equip, Potchefstroom, South Africa), CA-Seeder 1000 (Morrison Seeders, Unicoi, USA) and John Deere MaxEmerge Conservation Planter (John Deere, Moline, IL, USA) (control) (Table 1). Each plot was $4.6 \mathrm{~m} \times 9.1 \mathrm{~m}$. Buffers that were $4.6 \mathrm{~m}$ in length were placed between each set of four plots and a $1.5 \mathrm{~m}$ buffers were placed around each experimental area. The operator planted the middle four rows; the CA-Seeder 1000 planted the outer two border rows of each plot for all treatments except the six-row John Deere MaxEmerge.

Table 1. Specifications of seven maize seeders

\begin{tabular}{|c|c|c|c|c|c|c|}
\hline Seeder & Type & Weight & Seed type & $\begin{array}{l}\text { Seeding } \\
\text { depth }\end{array}$ & $\begin{array}{l}\text { Fertilizer } \\
\text { Application }\end{array}$ & Internal Mechanism \\
\hline Dibble stick & Tapered pry bar & $7.9 \mathrm{~kg}$ & Any & Variable & None & None \\
\hline OSU Green-seeder & $\begin{array}{l}\text { Mechanized } \\
\text { stick/dibble } \\
\text { seeder }\end{array}$ & $1.9 \mathrm{~kg}$ & $\begin{array}{l}\text { Any seed weighing } \\
\text { between } 0.20 \text { to } 0.30 \\
\mathrm{~g}\end{array}$ & Variable & Granular & $\begin{array}{l}\text { Seed metering delivery system } \\
\text { with a reciprocating drum, } \\
\text { spring and brush }\end{array}$ \\
\hline Li Seeder & $\begin{array}{l}\text { Mechanized } \\
\text { hoe }\end{array}$ & $2.2 \mathrm{~kg}$ & Large, flat & Variable & $\begin{array}{l}\text { Hopper } \\
\text { attached }\end{array}$ & Inertia-dependent seed meter \\
\hline Brazilian Jab & $\begin{array}{l}\text { Jab-dibble } \\
\text { instrument }\end{array}$ & $3.3 \mathrm{~kg}$ & Large, flat & Variable & $\begin{array}{l}\text { Hopper } \\
\text { attached }\end{array}$ & $\begin{array}{l}\text { Sliding seed meter to delivery } \\
\text { tube to planting tip; fixed seed } \\
\text { spacing }\end{array}$ \\
\hline $\begin{array}{l}\text { Haraka rolling Jab } \\
\text { Seeder }\end{array}$ & Punch seeder & $23 \mathrm{~kg}$ & $\begin{array}{l}\text { Maize, beans, cow } \\
\text { peas, sorghum }\end{array}$ & $\sim 4.57 \mathrm{~cm}$ & None & $\begin{array}{l}\text { Star wheel as seed meter with } 6 \\
\text { punch tips }\end{array}$ \\
\hline CA-Seeder 1000 & $\begin{array}{l}\text { Riding } 2 \text { wheel } \\
\text { seeder }\end{array}$ & $49.9 \mathrm{~kg}$ & Maize & Adjustable & Adjustable & Dual chamber seed meter \\
\hline $\begin{array}{l}\text { John Deere } 7200 \\
\text { MaxEmerge } \\
\text { Conservation Planter }\end{array}$ & $\begin{array}{l}\text { Industrial } \\
\text { mechanized } \\
\text { seeder }\end{array}$ & $\begin{array}{l}\text { Approx. } \\
1,587.6 \mathrm{~kg}\end{array}$ & $\begin{array}{lr}\text { Maize, } & \text { Peanut, } \\
\text { Cotton, } & \text { Sorghum, } \\
\text { Sugar } & \text { beet, } \\
\text { Soybeans } & \end{array}$ & Adjustable & By attachment & $\begin{array}{l}\text { Vacuum seed meter: circular } \\
\text { rotatable seed disk }\end{array}$ \\
\hline
\end{tabular}




\subsubsection{Methods of Data Collection}

Soil properties were measured for both residue types at the time of planting, 4 May 2015 for the maize residue plots and 14 May 2015 for the soybean residue plots. Soil surface penetration resistance was measured at time of seeding (Godwin, 1991) using a Drop Cone Penetrometer. Soil moisture and bulk density samples were taken from each trial (USDA NRCS, 2004). Additional soil samples from both residue trials were taken in order to compare soil properties and obtain baseline measurements of $\mathrm{pH}$ and nutrients (University of Tennessee Soil, Plant and Pest Center, Nashville, TN, USA). Residue cover of each plot was measured using the Line Transect Method (Wollenhaupt and Pingry, 1991).

Seeders were evaluated on how closely their respective plant populations achieved the plant density of 84000 plants $\mathrm{ha}^{-1}$. Limited resources, terrain and precedence largely dictate farmer practice of planting density throughout the developing world but current practice in many regions of SSA, Central and South America and Asia is to hill seed (2-4 seeds per hill) at an average of $35 \mathrm{~cm}$ apart (Chim et al., 2014). As such, an objective of this study was to compare grain yield to differences in established plant populations from single-seed planting.

A metered PVC pipe marked with $15.2 \mathrm{~cm}$ increments was used to maintain uniform distance between manually spaced seeding holes. Control of seed rate and density are crucial to achieve plant stand uniformity.

Plant population was measured at the 3-leaf vegetative (V3) and the V6 growth stage (Gibson, 2014). For each plot the number of plants per $1 / 2470^{\text {th }}$ of a hectare $\left(1 / 1000^{\text {th }}\right.$ of an acre) $(5.32 \mathrm{~m})$ were counted on the two middle rows. Crop height (Yin et al., 2011) was measured with a meter stick by randomly selecting six plants from the two middle rows of each plot at V3 andV6 growth stages. Plant height was measured from the soil surface to the top of the extended flag leaf, and a mean plant height was calculated for each plot.

Given the small plot size and to mimic smallholder non-mechanized harvest techniques, the plots were harvested by hand. Maize was harvested 22 October 2015. Stalks from the middle two rows were counted and recorded 1.5 $\mathrm{m}$ inside the plot for $5.32 \mathrm{~m}$ length of row (Lauer, 2002). All ears were harvested in the same row length, and were counted and recorded. Husks were left on the ears to maintain moisture content at harvest time. All ears were transported in grain bags from Mt. Gilead, Ohio to the University of Tennessee, Knoxville to be processed. All leaves and husks were removed from ears and total ear weight was measured for each plot. Grain was then shelled from cob using a hand-powered rotary Maximizer ${ }^{\text {TM }}$ Corn Sheller (Pleasant Hill Grain, Hampton, USA). Total grain and the cob weight were measured and recorded. Grain moisture and test weight were measured using a Dickey-John Mini Gac Moisture Tester ${ }^{\mathrm{TM}}$ (Dickey-John, Auburn, USA). Dry grain weight was corrected to $15.5 \%$ moisture and ear-stalk ratio was calculated using recorded counts of each per row (Lauer, 2002). Because of the difference in plant population, an ear-stalk calculation was made to accompany grain yield data, similar to other studies comparing maize varieties in silage production using ear-stalk ratios (Hemken et al., 1971; Bryant et al., 1966).. In this way, the seeders would be compared based on the numbers of ears present on each stalk.

\subsection{Economic Evaluation of Hand Seeders}

For this second objective, the five hand seeders (dibble stick, OSU Greenseeder, Li Seeder, Brazilian Jab, Haraka rolling) were evaluated based on their market price, crop seeding capacity and usability by the operator. Data for crop seeding capacity was collected from the same trial plots on the maize and soybean residues as mentioned above at the time of seeding.

For the purpose of this study, socio-economic assessment is focused on market price and effective field capacity of the seeders projected over smallholder farms in major regions of the developing world. Effective field capacity, as used in this study, refers to time needed for the machinery to cover a given area (usually ac $\mathrm{hr}^{-1}$ ) (ASABE, 2015; Hanna, 2002). Efficient operation of machinery - however mechanized or un-mechanized - is critical to the success of that machinery (Lar et al., 2011; Amiama et al., 2008).

The purchase price for each planter was obtained from the manufacturer of each technology (Lazarus and Selly, 2002). Prices were then projected on average smallholder farm sizes in countries from major regions of the developing world, namely Uganda (SSA), Tunisia (North Africa), Malaysia (Southeast Asia), Guatemala (Central America) and Bolivia (South America). Projection was done by dividing the market price (in both USD and the currency of the country) by the number of ha of the average farm size for the country. This was performed to consider the price $\mathrm{ha}^{-1}$ for the average smallholder farmer for each seeder technology in different countries. Values are reported in USD and the currency of each country under consideration (currency year 2016).

Effective field capacity data was collected at the time of planting (10 May for maize residue plots and 14 May 14 
for soybean residue plots) using the StopWatch Log App (Portable Databases, Raleigh, USA) (Bamgboye, 2006). The measurement of effective field capacity in the US is generally made in ac $\mathrm{hr}^{-1}$ or ha hr. ${ }^{-1}$ and is suited for mechanized operations. For manual operations, however, this unit is not reasonable as many hours would be needed to cover one hectare. For this reason, crop-seeding capacity, which can be considered the inverse of effective field capacity, is the term used in this study to describe the amount of time required to perform a function by hand in hr. ha ${ }^{-1}$. To measure the crop-seeding capacity of the five seeders, time was measured for every row $(9.1 \mathrm{~m})$ in each replicate. In-field results were projected over average smallholder farms in the six major areas of the developing world to indicate the mean time to seed smallholder farms from major regions of the developing world.

\subsection{Qualitative Evaluation of Hand Seeders}

Qualitative assessments were conducted using a ranking system based on environmental triangulation (Patton, 1990; Bodgan and Taylor, 1975), a qualitative research method, which utilizes different locations, settings, or variables that may influence the testing and findings in each scenario. Environmental triangulation was employed in the two residue environments to test seeder performance in the field (Guion et al., 2011). A comparison in seeder performance was made between each environmental condition. The ranking system was based on six criteria, each with predetermined indicators, and one overall ranking of performance (Table 2). The operator was a female (the author, 5'9", $140 \mathrm{lbs}$.) and implemented each hand seeder treatment.

Table 2. Qualitative ranking system

\begin{tabular}{|c|c|c|}
\hline Criteria & Indicators & Ranking Spectra \\
\hline Ease of transport to field & $\begin{array}{l}\text { - Pulled/Carried to field } \\
\text { - Cumbersome based on parts/dimensions } \\
\text { - Weight }\end{array}$ & $\begin{array}{l}10 \text { as easiest- } 1 \text { as most } \\
\text { difficult }\end{array}$ \\
\hline $\begin{array}{l}\text { Ease of Use/Usability while } \\
\text { planting }\end{array}$ & $\begin{array}{l}\text { - Weight } \\
\text { - Suggested motion for planting } \\
\text { - Seed to soil contact }\end{array}$ & $\begin{array}{l}10 \text { as good usability }-1 \text { as } \\
\text { poor usability }\end{array}$ \\
\hline Effort & $\begin{array}{l}\text { - Weight } \\
\text { - Motion of planting } \\
\text { - Seed to hole method } \\
\text { - Handling in residue }\end{array}$ & $\begin{array}{l}10 \text { as least effort }-1 \text { as most } \\
\text { effort }\end{array}$ \\
\hline Ease of handling Seed & $\begin{array}{l}\text { - Seed loading } \\
\text { - Seed storage while planting } \\
\text { - Seed capacity } \\
\text { - Seed to hole method }\end{array}$ & $\begin{array}{l}10 \text { as easiest- } 1 \text { as most } \\
\text { difficult }\end{array}$ \\
\hline $\begin{array}{l}\text { Use over } 480 \mathrm{FT} \\
\text { (4 rows } x 4 \text { reps) }\end{array}$ & $\begin{array}{l}\text { - Difficulty of motion } \\
\text { - Degree of wear on hands/back } \\
\text { - Required maintenance } \\
\text { - Malfunctions }\end{array}$ & $\begin{array}{l}10 \text { as easiest- } 1 \text { as most } \\
\text { difficult }\end{array}$ \\
\hline Ease of Seed-soil contact & $\begin{array}{l}\text { - Manual- under foot } \\
\text { - With implement }\end{array}$ & $\begin{array}{l}10 \text { as easiest- } 1 \text { as most } \\
\text { difficult }\end{array}$ \\
\hline $\begin{array}{l}\text { Overall Qualitative } \\
\text { Assessment }\end{array}$ & Above criteria added and seeders ranked & 10 as best -1 as poor \\
\hline
\end{tabular}

\subsection{Statistical Analysis}

Residue cover, plant population, crop height, grain yield, ear-stalk ratio, test weight and crop seeding capacity were analyzed using mixed models analysis of variance in SAS 9.4 (Cary, NC, USA). Least squares means were separated using least significant difference test at $\alpha=0.05$. To mitigate variation from differences in residue, a 
covariate on residue was tested but was found significant $(\mathrm{p}<0.05)$ in only one data set and so was not applied to any data sets.

\section{Results and Discussion}

\subsection{Crop Growth, Development and Yield Measurements for Maize for Seven Seeders}

Overall results of crop growth, development and yield were greatly affected by highly unusual rainfall patterns in 2015 including $643 \mathrm{~mm}$ of rainfall during the growing season (May to October) compared to the regional average of $591 \mathrm{~mm}$. The distribution of this rainfall was incongruous to crop needs: abnormally high at the time of fertilizer application in June, but low at the time of planting, crop root establishment, and the beginning of crop reproductive stages. Nearly $500 \mathrm{~mm}$ fell over a 22-day period, $200 \mathrm{~mm}$ of which occurred during a six-day period, followed by severe plant stress at silking due to drought conditions. Despite this abnormality, these seeding conditions mimic even more acutely the conditions of the smallholder grower with unwieldy weather patterns and stressed growing conditions.

Surface residue cover between seeder treatments was statistically insignificant in both residue types; the seeders were being evaluated on the same percent surface cover within the maize residue plots and the soybean residue plots. Average surface cover in the maize and soybean residue plots was 91 and $61 \%$, respectively. Soil surface penetration resistance was measured at $6.85 \mathrm{~mm}$ in the maize residue and $5.65 \mathrm{~mm}$ in the soybean residue, indicating deeper penetration (Godwin, 1991) and therefore a softer soil surface in the maize residue plots. Three seed wheel spokes broke on the metering device of the Haraka rolling after $13.7 \mathrm{~m}$ of planting in the maize residue. It is presumed that the high amount of residue proved too much resistance for this seeder. For this reason, the Haraka rolling seeder treatment was not used on all replications and was excluded from data analysis in both trials. It should also be noted that this was the most expensive human powered implement in this study and would need significant improvement and further trials before being promoting in CA smallholder production.

\subsubsection{In-Season Crop Measurements: Plant Population and Crop Height}

The dibble stick, CA-Seeder 1000, and John Deere MaxEmerge were tested and were expected to be the most reliable in establishing the desired plant population for the control because of the $100 \%$ manual operation in the dibble and highly mechanized control in the CA-Seeder 1000 and John Deere MaxEmerge. In the maize residue trial, significant differences were found between seeder planting densities $(p<0.001)$ with the dibble stick achieving the closest to desired 84000 plants ha $^{-1}$ at 77000 plants ha ${ }^{-1}$ (Table 3). The Brazilian Jab and Li Seeder had significantly higher populations at 93000 and 99000 plants $^{-1} \mathrm{r}^{-1}$, respectively. These two seeders both displayed similar difficulty in the non-plowed conditions: their seed meter mechanism was very sensitive to a harder soil surface and to residue causing more seeds to be released than expected. The most primitive of instruments performed equally well to the most mechanized seeders in establishing a plant population, as the dibble stick planting density was not different from the John Deere and the CA-Seeder 1000 (Table 3). The OSU Greenseeder had significantly lower plant populations than the desired density - operator notes indicate that seed bounced off of residue from the moment it left the end of the hopper and fell toward the hole.

In the soybean residue trial, significant differences were also found between seeder planting densities $(\mathrm{p}<0.0001)$ with the dibble stick again achieving closest to the desired population (Table 3). The Brazilian Jab and the Li Seeder had excessively high populations at 183000 and 175000 plants ha $^{-1}$ respectively, while the remaining treatments had plant populations significantly closer to the target of 84000 plants ha $^{-1}$ (Table 3). Similar to their performance in the maize residue plots, the seed metering mechanisms in the Brazilian Jab and the Li Seeder were easily disrupted by the impacts with hard soil surfaces and more seeds were dispensed as a result. The waste of seed in this instance indicates the need for improvement to the sensitivity of the seed metering mechanism if these seeders are to be employed on harder soil surfaces found in no-till environments and reduce wasting seed for the smallholder farmer.

In the maize residue trial, significant differences were found between seeder crop heights $(\mathrm{p}<0.05)$ at the V3 growth stage (Table 3). The CA-Seeder 1000 had the highest crop height at $33.4 \mathrm{~cm}$ but was not significantly different from the Brazilian Jab or the Li Seeder (Table 3). The John Deere had the lowest crop height at $26.0 \mathrm{~cm}$ and was significantly different from OSU Greenseeder and the dibble stick (Table 3). The Brazilian Jab, Li Seeder, OSU Greenseeder and the dibble stick had statistically equal crop height, highlighting a similar planting depth among these seeders that yielded similar crop heights at this growth stage (Table 3). By the V6 Growth stage, the treatment effects appear to have diminished and no significant differences were found between the crop heights of the treatments.

In the soybean residue trial, significant differences were also found between seeder crop heights at the V3 
Growth stage $(\mathrm{p}=0.0370)$ (Table 3). The OSU Greenseeder had the highest crop height at $59.5 \mathrm{~cm}$, which was not significantly different from the Brazilian Jab, the dibble stick, the CA-Seeder 1000, and the Li Seeder. These treatments were significantly higher than the John Deere at $44.7 \mathrm{~cm}$ (Table 3). Reiterating the findings from the maize residue plots, differences in planting depth can be intimated, affecting inter-crop competition, root establishment and crop height. The higher crop height of the dibble stick and OSU Greenseeder planted treatments could be the result of stronger root establishment if a more ideal planting depth for nutrient and water uptake was achieved. The John Deere MaxEmerge's low crop height is not well understood, considering it had the most consistent seeding depth and plant spacing. However, no row cleaners were used to ensure a true no-till environment, resulting in colder seed zone, which would produce slower growth rates. By the V6 growth stage, treatment effects between seeders had diminished, similar to the maize residue crops. The dibble stick had the greatest crop height at $91.4 \mathrm{~cm}$ but there was no significant difference between any crop heights of the seeders $(\mathrm{p}>0.05)$ (Table 3). Stalk elongation and leaf production occluded differences in planting depth and plant density.

\subsubsection{Harvest Measurements: Grain Yield, Ear-Stalk Ratio and Test Weight}

In the maize residue trial, grain yield data indicated the OSU Greenseeder acheived the highest mean grain yield at $4.83 \mathrm{~T} \mathrm{ha}^{-1}$ but was not significantly different than all other treatments in grain yield $(\mathrm{p}>0.05)$ (Table 3$)$. The mean grain yields then decreased from CA-Seeder 1000, Brazilian Jab, dibble stick, John Deere MaxEmerge, to the Li Seeder at $3.04 \mathrm{~T} \mathrm{ha}^{-1}$. In the soybean residue trial, grain yield data also found no significant differences between seeders $(\mathrm{p}=0.1285)$ - the hand seeders performed equally as well as the CA-Seeder 1000 riding seeder and the John Deere MaxEmerge (Table 3). The highest grain yield was the dibble stick at $3.40 \mathrm{~T} \mathrm{ha}^{-1}$ followed by the John Deere MaxEmerge, CA-Seeder 1000, the OSU Greenseeder, the Li Seeder, and Brazilian Jab at 0.87 T $\mathrm{ha}^{-1}$. Despite significant differences in plant populations and differences in planting depth across both residue types, hand seeders achieved comparable yields to the most mechanized and developed technology in the study. Such findings highlight that lower yields in the developing world do not necessarily stem from a lack of technology in seeding and focus should possibly be turned to improving soil fertility. The comparative labor involved in seeder technology for the developing world, however, should be the focus of developers and the NGOs collaborating in development.

In the maize residue trial, the ear-stalk ratio results complement the grain yield findings and indicated no significant differences between treatments ( $p>0.05)$, but all treatments acheived mean ratios lower than 1 ear per stalk (Table 3). These results suggest all seeders, despite varying planting depths, had difficulty under the abnormal climatic conditions of the growing season.

In the soybean residue trial, differences in ear-stalk ratio were significant $(p<0.0001)$ with the CA-Seeder 1000 achieving the highest at 0.92 ears/stalk, not significantly different from the dibble stick and the John Deere; these seeders exist on either extremes of mechanization and provided comparable results (Table 3). The highest of the middle mechanization seeders, the Brazilian Jab, the OSU Greenseeder and the Li Seeder, was the OSU Greenseeder at 0.76 ears/stalk. The fact that none of the seeders obtained the expected 1:1 ratio that would be expected point to the abnormality of the climate during this growing season and also the result of seeders leaving unplanted seed on the surface. Comparisons between the seeders do suggest that the Li Seeder and the Brazilian jab's high plant populations were a detriment to their ability to produce ears on all stalks. Grain quality was considered after noticeable difference in grain quality between the dibble stick, John Deere MaxEmerge, CA-Seeder 1000 and the Brazilian Jab and Li Seeder. Test weight results, however did not indicate significance between seeders $(\mathrm{p}>0.05)$. Future investigation into grain quality is highly recommended to compare seeder performance for the smallholder farmer. 
Table 3. In season and yield results of all seeders for both residue types

\begin{tabular}{|c|c|c|c|c|c|c|}
\hline Residue & Seeder* & 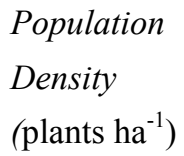 & $\begin{array}{l}\text { Crop height } \\
V 3(\mathrm{~cm})\end{array}$ & $\begin{array}{l}\text { Crop height V6 } \\
(\mathrm{cm})\end{array}$ & $\begin{array}{l}\text { Grain } \\
\text { Yield } \quad(T \\
\left.\mathrm{ha}^{-1}\right)\end{array}$ & Ear/Stalk \\
\hline \multirow[t]{8}{*}{ Maize } & Dibble stick & $77000 \mathrm{~b}$ & $29.2 b c$ & $80.5 a$ & $3.15 a$ & $0.90 a$ \\
\hline & OSU Greenseeder & $53000 c$ & $29.5 b c$ & $86.8 a$ & $4.83 a$ & $0.93 a$ \\
\hline & Li Seeder & $99000 a$ & $28.8 a b$ & $92.7 a$ & $3.04 a$ & $0.80 a$ \\
\hline & Brazilian Jab & $93000 a$ & $30.0 a b$ & $83.5 a$ & $3.20 a$ & $0.82 a$ \\
\hline & CA-Seeder 1000 & $70000 \mathrm{~b}$ & $33.4 a$ & $87.8 a$ & $3.90 a$ & $0.92 a$ \\
\hline & John Deere & $72000 \mathrm{~b}$ & $26.0 c$ & $78.7 a$ & $3.11 a$ & $0.90 a$ \\
\hline & MaxEmerge & & & & & \\
\hline & P values & $P<0.001$ & $P<0.05$ & $P>0.05$ & $P>0.05$ & $P>0.05$ \\
\hline \multirow[t]{8}{*}{ Soybean } & Dibble stick & $84000 \mathrm{~b}$ & $56.6 a$ & $91.4 a$ & $3.40 a$ & $0.85 a b$ \\
\hline & OSU Greenseeder & $107000 b$ & $59.5 a$ & $85.0 a$ & $1.51 a$ & $0.76 b$ \\
\hline & Li Seeder & $175000 a$ & $53.1 a b$ & $79.4 a$ & $1.01 a$ & $0.43 c$ \\
\hline & Brazilian Jab & $183000 a$ & $55.8 a$ & $80.2 a$ & $0.87 a$ & $0.35 c$ \\
\hline & CA-Seeder 1000 & $72000 \mathrm{~b}$ & $55.5 a$ & $81.0 a$ & $2.27 a$ & $0.92 a$ \\
\hline & John Deere & $78000 \mathrm{~b}$ & $44.7 b$ & $78.3 a$ & $2.30 a$ & $0.87 a b$ \\
\hline & MaxEmerge & & & & & \\
\hline & Pvalues & $P<0.0001$ & $P=0.0370$ & $P>0.05$ & $P=0.1285$ & $P<0.0001$ \\
\hline
\end{tabular}

* Means separated down each column using the least significant difference test at $\alpha=0.05$

\subsection{Economic Evaluation of Hand Seeders}

\subsubsection{Projection of Purchase Price on Average Smallholder Farm Size}

For most smallholder farmers, new equipment is a significant investment. Numerous considerations exist when deciding on farm equipment, such as cost per unit area, depreciation, useful life, shipping and distribution, maintenance, risk preferences, cultural and gender dynamics, among others. A detailed analysis of each of these considerations is beyond the scope of this study but each is crucial to address before new technologies are introduced, donated or promoted to smallholder farmers of the world. For the purpose of this study, the purchase price was compared between all seeders (Table 4), ranging from a price of $\$ 0.00$ for the dibble stick to $\$ 235.07$ for the Haraka rolling. No cost was assumed for the dibble stick, as this technology is most often sourced from local materials and made by the farmer. The OSU Greenseeder, the Li Seeder and the Brazilian Jab are aligned in the same middle price range whereas the Haraka's high price suggests this technology is intended for cooperatives of farmers or the large-scale end of smallholder agriculture.

Table 4 reports the market price of each seeder and the projected cost ha ${ }^{-1}$ for each seeder in the country of interest (exchange rates from 2016, NYSE, N2SE Arca LLC, and NYSE MKT LLC); the countries included were from the major regions of the developing world including Uganda (SSA), Tunisia (North Africa), Malaysia (Asia-Pacific), Guatemala (Central America), and Bolivia (South America). The average smallholder farm sizes for these countries are Uganda at $2.5 \mathrm{ha}$, Tunisia at $4.3 \mathrm{ha}$, Malaysia at 1.5 ha, Guatemala at 1.14 ha and Bolivia at 2.95 ha (AfDB, 2009; Shaw, 2015; Chee, 1998; Immink, 1992; FAO, 2016, respectively). Reported in USD and the country's currency, the cost $\mathrm{ha}^{-1}$ ranges from 6.64 USD ha ${ }^{-1}$ for the Li Seeder in Tunisia to as much as 206.20 USD ha ${ }^{-1}$ for the Haraka in Guatemala. This study cannot state what is an unreasonable price for a smallholder farmer from each country - that decision is for each individual farmer. The data strongly suggests, however, a great need to document the projected costs for hand seeder technologies for a given area so that governments, NGOs and individuals can make more accurate investments. 
Table 4. Purchase price of 5 seeders and cost ha ${ }^{-1}$ for average smallholder farm sizes in 6 regions of the developing world

\begin{tabular}{|c|c|c|c|c|c|c|}
\hline Seeders & $\begin{array}{l}\text { Purchase } \\
\text { price } \\
\text { (USD) }\end{array}$ & $\begin{array}{l}\text { Cost ha }{ }^{-1} \\
\text { Average } \\
\text { Smallholder } \\
\text { farm Uganda } \\
\text { (USD/Ugandan } \\
\text { shilling, UGX) }\end{array}$ & $\begin{array}{l}\text { Cost } \text { ha }^{-1} \\
\text { Average } \\
\text { Smallholder } \\
\text { farm in } \\
\text { Tunisia, } \\
\text { North Africa } \\
\text { (USD/ } \\
\text { Tunisian } \\
\text { dinar, TND) }\end{array}$ & $\begin{array}{l}\text { Cost } \text { ha }^{-1} \\
\text { Average } \\
\text { Smallholder } \\
\text { farm Malaysia, } \\
\text { Asia-Pacific } \\
\text { (USD/Malaysian } \\
\text { Ringgit, MYR) }\end{array}$ & $\begin{array}{l}\text { Cost } \text { ha }^{-1} \\
\text { Average } \\
\text { Smallholder } \\
\text { farm } \\
\text { Guatemala } \\
\text { (USD/ } \\
\text { Guatemalan } \\
\text { Quetzal, GTQ) }\end{array}$ & $\begin{array}{l}\text { Cost ha }{ }^{-1} \\
\text { Average } \\
\text { Smallholder } \\
\text { farm Bolivia } \\
\text { (USD/ } \\
\text { Bolivian } \\
\text { boliviano, } \\
\text { BOB) }\end{array}$ \\
\hline Dibble stick & 0.00 & 0.00 & 0.00 & 0.00 & 0.00 & 0.00 \\
\hline $\begin{array}{l}\text { OSU } \\
\text { Green-seeder }\end{array}$ & 25.00 & $\begin{array}{c}10.00 / \\
35930.00\end{array}$ & $\begin{array}{l}5.81 / \\
13.30\end{array}$ & $\begin{array}{c}16.67 / \\
74.11\end{array}$ & $\begin{array}{l}21.93 / \\
125.07\end{array}$ & $\begin{array}{c}8.47 / \\
115.52\end{array}$ \\
\hline Li Seeder & 28.57 & $\begin{array}{c}11.43 / \\
38112.38\end{array}$ & $\begin{array}{l}6.64 / \\
13.64\end{array}$ & $\begin{array}{l}19.05 / \\
79.05\end{array}$ & $\begin{array}{l}25.06 / \\
192.67\end{array}$ & $\begin{array}{l}9.70 / \\
66.44\end{array}$ \\
\hline Brazilian Jab & 31.00 & $\begin{array}{c}12.40 / \\
41354.00\end{array}$ & $\begin{array}{l}7.21 / \\
14.81\end{array}$ & $\begin{array}{l}20.67 / \\
85.77\end{array}$ & $\begin{array}{l}27.19 / \\
209.05\end{array}$ & $\begin{array}{l}10.53 / \\
72.13\end{array}$ \\
\hline $\begin{array}{l}\text { Haraka } \\
\text { rolling }\end{array}$ & 235.07 & $\begin{array}{c}94.03 / 313 \\
583.38\end{array}$ & $\begin{array}{l}54.67 / \\
112.29\end{array}$ & $\begin{array}{l}156.71 / \\
650.27\end{array}$ & $\begin{array}{l}206.20 / \\
1585.37\end{array}$ & $\begin{array}{l}79.82 / \\
546.77\end{array}$ \\
\hline
\end{tabular}

In Table 5, the market price of the seeders is projected over farmer income in Uganda. Uganda is used as a case study to highlight the percentage of income and days of labor wages each technology represents. With an average smallholder farm size of $2.5 \mathrm{ha}$, it would cost approximately 11.43 USD or 38 113.38 USh (Ugandan shilling) ha ${ }^{-1}$ to purchase the Li seeder and as much as 313585.38 USh ha $^{-1}$ for the Haraka rolling (Muth, 2011). When the average farmer income in Uganda is 795.70 USD year $^{-1}$ or 2679917.60 USh year $^{-1}$, the OSU Greenseeder represents $3.14 \%$ of yearly income or 11.47 days of labor wages as opposed to the and the Haraka rolling represents $29.54 \%$ of yearly income or 107.83 days of labor wages in Uganda. The Li Seeder and Brazilian Jab seeders were in between the OSU and the Haraka rolling Seeder (Table 5).

Table 5. Seeder price based on average smallholder farmer income in Uganda

\begin{tabular}{llll}
\hline Seeders & Purchase price (USD) & \% of Yearly Income & Days of labor wages \\
\hline Dibble stick & 0.00 & 0.00 & 0.00 \\
OSU Greenseeder & 45.00 & $3.14 \%$ & 11.47 days \\
Li Seeder & 28.57 & $3.59 \%$ & 13.11 days \\
Brazilian Jab & 31.00 & $3.89 \%$ & 14.22 days \\
Haraka rolling & 235.07 & $29.54 \%$ & 107.53 days \\
\hline
\end{tabular}

Overall, the data underscore an idea prevalent in studies addressing mechanization in the developing world: "appropriate mechanization" (Baudron, 2015). Appropriate mechanization refers to the technological advancement and mechanization balanced with economic viability and usability (Mrema, 2008; Baudron, 2015). The correlation between mechanization and cost is clear - as mechanization increases, so does cost. Therefore, the increased performance over baseline methods afforded with increased mechanization must be significant for the farmer or adoption will be minimal.

\subsubsection{Crop Seeding Capacity and Projections on Smallholder Farm Sizes}

Each seeder was evaluated in the field based on the time it took to seed a given area or crop-seeding capacity. 
Results show significant differences between crop-seeding capacity in the five seeders $(\mathrm{p}<0.0001)$ - the Haraka (although anecdotal data due to its breakdown in the first replicate) was the fastest followed by the Li Seeder, Brazilian Jab, OSU Greenseeder, and the dibble stick $(\mathrm{p}<0.0001)$ (Figure 1). Although differences in crop-seeding capacities are a function of the operator, soil type, residue cover and weather conditions, they highlight the extremes in mechanization between the lower crop-seeding capacity (but reliable) dibble stick and higher crop-seeding capacity (yet less reliable) Haraka rolling. The three seeders in the middle of spectrum--the Brazilian Jab, Li Seeder and OSU Greenseeder-provide a middle ground between a moderate crop-seeding capacity and low mechanization. The idea of "appropriate mechanization" pertains again as the need to improve crop-seeding capacity grows but not at the cost of reliability and expense.

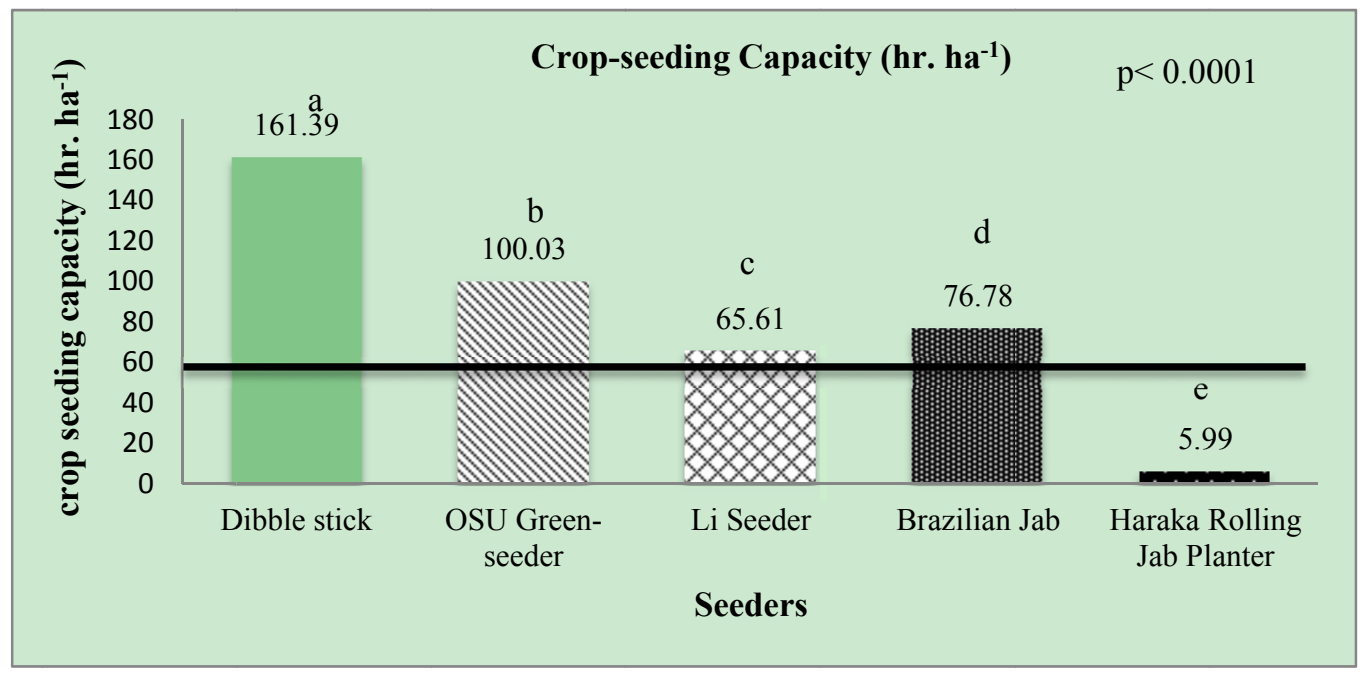

Figure 1. Crop seeding capacity of five hand seeders

In Table 6, the in-field measurements of crop-seeding capacity in hr. ha ${ }^{-1}$ are shown in increasing order of mechanization of the seeders. Based on the average farm size for each of the six major areas of the developing world (Note 2), the planting time required between seeders ranges from $6.4 \mathrm{hr} \mathrm{ha}^{-1}$ crop-seeding capacity of the Haraka on an average smallholder farm in developing Asia up to $8182.6 \mathrm{hr}^{-\mathrm{ha}^{-1}}$ crop-seeding capacity of the dibble stick on an average smallholder farm in South America (Table 6). These results cannot claim a threshold for crop-seeding capacities in these regions - such decisions reside with an individual farmer-but, these results illustrate a need for recommendations of tools based on farm size; recommendations that could be researched and maintained by extension in country, similar to fertilizer recommendations by state in the U.S. Providing researched recommendations for a region of smallholder farmers using crop-seeding capacity could aid the individual farmers to know which hand seeders and levels of mechanization fit their needs. 
Table 6. Crop-seeding capacity (hr. ha ${ }^{-1}$ ) for five hand seeders and projected over 6 regions of the developing world

\begin{tabular}{|c|c|c|c|c|c|c|c|c|}
\hline Seeder & $\begin{array}{l}\text { Hr. } \\
\mathrm{ha}^{-1} \\
\text { in } \\
\text { field }\end{array}$ & $\begin{array}{l}\text { Hr. ha }{ }^{-1} \text { for } \\
\text { average } \\
\text { smallholder } \\
\text { farm in } \\
\text { SSA }\end{array}$ & $\begin{array}{l}\text { Hr. ha }{ }^{-1} \text { for } \\
\text { average } \\
\text { smallholder } \\
\text { farm Near } \\
\text { East and } \\
\text { North } \\
\text { Africa }\end{array}$ & $\begin{array}{l}\text { Hr. ha }{ }^{-1} \text { for } \\
\text { average } \\
\text { smallholder } \\
\text { farm Asia } \\
\text { (developing) }\end{array}$ & $\begin{array}{l}\text { Hr. ha }^{-1} \text { for } \\
\text { average } \\
\text { smallholder } \\
\text { farm } \\
\text { Pacific }\end{array}$ & $\begin{array}{l}\text { Hr. ha }{ }^{-1} \text { for } \\
\text { average } \\
\text { smallholder } \\
\text { farm } \\
\text { Central } \\
\text { America } \\
\text { and the } \\
\text { Caribbean }\end{array}$ & $\begin{array}{l}\text { Hr. ha }{ }^{-1} \text { for } \\
\text { average } \\
\text { smallholder } \\
\text { farm South } \\
\text { America }\end{array}$ & $\begin{array}{l}\text { Hr. ha }{ }^{-1} \text { for } \\
\text { average } \\
\text { smallholder } \\
\text { farm all } \\
\text { developing } \\
\text { countries }\end{array}$ \\
\hline $\begin{array}{l}\text { Dibble } \\
\text { stick } \\
\text { OSU }\end{array}$ & 161.4 & 209.8 & 677.9 & 171.1 & 936.1 & $3,582.9$ & $8,182.6$ & 435.8 \\
\hline $\begin{array}{l}\text { Green-se } \\
\text { eder }\end{array}$ & 100.0 & 130.0 & 420.1 & 106.0 & 580.2 & $2,220.7$ & $5,071.6$ & 270.1 \\
\hline $\begin{array}{l}\mathrm{Li} \\
\text { Seeder }\end{array}$ & 65.6 & 85.3 & 275.6 & 69.6 & 380.5 & $1,456.6$ & $3,326.5$ & 177.2 \\
\hline $\begin{array}{l}\text { Brazilian } \\
\text { Jab }\end{array}$ & 76.8 & 99.8 & 322.5 & 81.4 & 445.4 & $1,704.6$ & $3,893.0$ & 207.3 \\
\hline $\begin{array}{l}\text { Haraka } \\
\text { rolling } \\
\text { Seeder }\end{array}$ & 6.0 & 7.8 & 25.1 & 6.4 & 34.7 & 132.9 & 303.5 & 16.2 \\
\hline
\end{tabular}

These results point to the importance of appropriate mechanization and the need for detailed analyses of smallholder technology in country. In this case, lower mechanization seeders may not be suitable for larger smallholder farms in Central America and South America whereas smallholder farmers in SSA, Near East and North Africa could benefit from time saving higher mechanization than the dibble stick. The size of the farm has significant effect on the type of equipment a smallholder farmer needs to seed. Another key feature of the smallholder farm not addressed in this study is how marginal the landscape of the farm is - the degree of slope or depth to bedrock. For example, highly mechanized seeders tend to be larger and heavier and, as such, cannot be employed on a steep slope. The size and other characteristics of the smallholder farm are key determinants for identifying the appropriate hand seeders to employ.

\subsection{Qualitative Evaluation of Hand Seeders}

A qualitative assessment provides substantive user-oriented information and is necessary before technology is distributed or recommended. The results of this qualitative assessment of five hand seeders indicate disparity between the stated capabilities of a given technology and the in-field performance (Table 7). Performance evaluations (Gould et al., 1996; Aikins et al., 2010; Hossain et al., 2009; Smithers et al., 2010) suggest that hand seeder technology is heavily dependent on user-acceptance and general usability. There are no known studies that conducted qualitative analyses on hand seeders. Current literature and development efforts lack data that accompanies yield data with tests of usability of manual technology for smallholders.

Rankings of the five seeders indicate a general theme: ease of transport and ease of use were inversely related to the ease of handling seed, effort and ease of seed-soil contact. By increasing complexity, cuts were made to other criteria. The dibble stick was easy to transport to the field and easy to use but required significantly more effort than the Haraka rolling seeder, more difficult to transport and use. Between these extremes, the OSU Greenseeder provided the benefits of minimal mechanization, with high rankings in ease of handling seed, use over time and effort and minimal mechanization, with high rankings in ease of handling seed, use over time and effort and concurrently, provided the benefits of ease of transport and ease of use. Results for the Li Seeder and the Brazilian jab were similar - both provided enough mechanization to lower effort and handle seed internally 
but maintained a high ranking for ease of transport and ease of use. The OSU Greenseeder had the highest overall qualitative ranking among the five seeders.

Table 7. Qualitative ranking for five hand seeders

\begin{tabular}{|c|c|c|c|c|c|c|c|c|}
\hline \multirow[b]{2}{*}{ Seeders } & \multirow[b]{2}{*}{$\begin{array}{l}\text { Ergonomic } \\
\text { Form } \\
\text { Employed }\end{array}$} & \multicolumn{7}{|c|}{ Rankings (1 -10, See table 2. For ranking spectra) } \\
\hline & & $\begin{array}{l}\text { Ease of } \\
\text { transport } \\
\text { to field }\end{array}$ & $\begin{array}{ll}\text { Ease of } \\
\text { Use/Usability }\end{array}$ & Effort & $\begin{array}{l}\text { Ease of } \\
\text { handling } \\
\text { Seed }\end{array}$ & $\begin{array}{l}\text { Ease of } \\
\text { Seed-soil } \\
\text { contact }\end{array}$ & $\begin{array}{l}\text { Use over } \\
480 \mathrm{FT} \\
(4 \text { rows } \times 4 \\
\text { reps) }\end{array}$ & $\begin{array}{l}\text { Overall } \\
\text { Qualitative } \\
\text { Assessment }\end{array}$ \\
\hline $\begin{array}{c}\text { Dibble } \\
\text { stick }\end{array}$ & $\begin{array}{l}\text { Standing erect, } \\
90 \text { degree } \\
\text { bend to plant } \\
\text { seed }\end{array}$ & 10 & 8 & 3 & 2 & 3 & 2 & 28 \\
\hline $\begin{array}{c}\text { OSU } \\
\text { Green-see } \\
\text { der }\end{array}$ & Standing erect & 10 & 9 & 8 & 10 & 3 & 3 & 43 \\
\hline Li Seeder & $\begin{array}{c}\text { From Standing } \\
\text { erect to bent at } \\
90 \text { degrees }\end{array}$ & 10 & 7 & 6 & 10 & 3 & 3 & 39 \\
\hline $\begin{array}{c}\text { Brazilian } \\
\quad J a b\end{array}$ & $\begin{array}{c}\text { Standing, } \\
\text { slightly bent } \\
\text { from the lower } \\
\text { back }\end{array}$ & 8 & 7 & 6 & 10 & 3 & 4 & 38 \\
\hline $\begin{array}{c}\text { Haraka } \\
\text { rolling Jab } \\
\text { Seeder }\end{array}$ & Standing erect & 1 & 2 & 3 & 9 & 7 & 0 & 22 \\
\hline
\end{tabular}

\section{Conclusions}

The study found that despite the great range in mechanization, all of the seeders tested performed equally to the John Deere MaxEmerge and, in some cases, outperformed it with the exception of the Haraka rolling planter, which catastrophically failed while planting in the first replicate plot. Crop growth and development results highlighted differences in planting depth at early growth stages and plant populations between the seeders in both the soybean residue and the maize residue plots. These differences, however, were equalized by harvest with no significant differences in either residue type for grain yield. Comparable yields between treatments underscore that increased maize yields are not solely a function of the seeder or seeding depth but many other factors beyond the scope of this study may play a role, such as soil fertility, water holding capacity and climatic conditions and other key challenges to the smallholder farmer. Significant differences in ear-stalk ratios in the soybean residue indicate that the simplest seeding tool, the dibble stick, performed equally to the mechanized CA-Seeder 1000 and the John Deere MaxEmerge: plants without ears are not a viable use of farmer inputs and all other treatments were below 0.7 ears per stalk. The fact that ear-stalk ratios were not significantly different in the maize residue highlights that the harder the soil surface in the soybean residue presented more difficulty to the internal mechanisms in penetrating the soil surface and metering seed accurately.

The grain yield and ear-stalk ratio are not, however, indicative of the grain quality - as the ears from the higher plant populations of the Brazilian Jab and the Li Seeder were very small, difficult to process and more often moldy due to fungal infestation. This is most likely the result of high plant population and increased plant competition for nutrients and water.. Test weight results did not display these differences making further comparisons of grain quality between seeders necessary before making recommendations for seeders. Also 
worthy of exploration is the ergonomic biases of maize seeders, whether culturally or by gender and how research can explore the usability of current designs.

The results of this study point to the complexity providing improved technology to the millions of smallholder farmers and the supreme importance of multi-dimensional assessments of agricultural tools for smallholder farmers. Crop growth, development and yield studies are necessary to determine the worth of hand seeders but, when used alone, they fail to provide a complete picture of how successful the given technology will be. The usability, crop seeding capacity and cost of technologies are significant variables in the market of agricultural tools that are difficult to assess from country to country, even from individual to individual. Hand seeder development and technology also needs to be gender specific since women are largely responsible for the task of seeding, an arduous manual job associated with crop establishment. Failure to offer women the capacity to seed in CA will negate potential progress and future sustainability for the developing world. Addressing the role of women as the majority of those who seed crops remains a crucial step forward in the research and development of hand seeders for smallholder farmers.

But these challenges present many research opportunities with far-reaching and realistic benefits to smallholder farmers. For the good of the smallholder farmer from SSA to Southeast Asia, new technologies need to be thoroughly assessed and pay heed to those individuals who will use them. Smallholder farmers, seeding their crops in an increasingly unpredictable climate and under increasingly strained soil conditions, can employ CA to improve resilience and soil fertility in their cropping systems. To do so, these farmers need a tool, a technology to allow them to realize a CA model and, in so doing, achieved improved livelihoods for them and future generations.

\section{Acknowledgments}

I would like to thank my advisor, Neal S. Eash for his direction and constant support through this research. My colleagues, Casey Sullivan and Deb O'Dell, have been instrumental in the preparation, research and writing of this paper. Special thanks to John Goddard, an enormous support in the field and William E. Hart for his editorial assistance. This work is dedicated to the recently deceased John E. Morrison Jr. and his indelible work supporting smallholder farmers.

\section{References}

AfDB. (2009). African Development Bank Data Platform. Retrieved from http://intranet.afdb.org/portal/page/portal/AFDBPG_Research/02_Statistics/01_D evelopmentData

Africa, S. S. (2013). Agricultural Mechanization in Sub Saharan Africa. Integrated Crop Management, 22.

Aikins, S. H. M., Bart-Plange, A., \& Opoku-Baffour, S. (2010). Performance evaluation of jab seeders for maize planting and inorganic fertilizer application. ARPN Journal of Agricultural and Biological Science, 5(1), 29-33.

Altieri, M. A., \& Koohafkan, P. (2008). Enduring farms: Climate change, smallholders and traditional farming communities (Vol. 6). Third World Network (TWN).

Amiama, C., Bueno, J., \& Alvarez, C. J. (2008). Influence of the physical parameters of fields and of crop yield on the effective field capacity of a self-propelled forage harvester. Biosystems Engineering, 100(2), 198-205. https://doi.org/10.1016/j.biosystemseng.2008.03.004

ASABE. (2015). ASAE EP496.3 FEB2006 (R2015) Agricultural machinery management data. ASABE Standards 2015. St. Joseph, Mich.: ASABE.

Bamgboye, A. I., \& Mofolasayo, A. S. (2006). Performance evaluation of a two-row okra planter. Agricultural Engineering International: CIGR Journal.

Baudron, F., Sims, B., Justice, S., Kahan, D. G., Rose, R., Mkomwa, S., ... Gérard, B. (2015). Re-examining appropriate mechanization in Eastern and Southern Africa: two-wheel tractors, conservation agriculture, and private sector involvement. Food Security, 7(4), 889-904. http://doi.org/10.1007/s12571-015-0476-3

Bodgan, R., \& Taylor, S. J. (1975). Introduction to qualitative research methods. New York.

Bruinsma, J. (2003). World agriculture: towards 2015/2030: an FAO perspective. Earthscan.

Bryant, H. T., Blaser, R. E., Hammes, R. C., \& Huber, J. T. (1966). Evaluation of corn silage harvested at two $\begin{array}{lllll}\text { stages of maturity. } & \text { Agronomy } & \text { Journal, }\end{array}$ https://doi.org/10.2134/agronj1966.00021962005800030003x

Chee, W. C., \& Abdulla, A. (1998). Country pasture/forage resource profiles, Malaysia. Ministry of Agriculture 
Malaysia, Kuala Lumpur.

Chim, B. K., Omara, P., Macnack, N., Mullock, J., Dhital, S., \& Raun, W. (2014). Effect of seed distribution and population on maize (Zea mays L.) grain yield. International Journal of Agronomy.

Comsec. (1990). Report of expert consultation on agricultural mechanization in Commonwealth Africa. Commonwealth Secretariat, Malborough House, Pall Mall London SW1Y511X:83.

Csaki, C., \& de Haan, C. (2003). Reaching the rural poor: a renewed strategy for rural development. World Bank Publications. https://doi.org/10.1596/0-8213-5459-0

Du, B., Bekele, A., \& Morrison Jr, J. E. (2004). Drill furrow opener effects on wheat and sorghum establishment in no-till fields. Applied engineering in agriculture, 20(2), 179. https://doi.org/10.13031/2013.15888

FAO. (2010). Conservation Agriculture of Natural Resources for Sustainable Agriculture. Food and Agriculture Organization, Rome. Retrieved from http://www.fao.org/ag/ca/Training_Materials/guide_tools_equipment_animal.pdf

FAO. (2011). The state of food and agriculture 2010-2011. Food \& Agriculture Organization of the UN (FAO).

FAO. (2012). Smallholders and Family Farmers. Sustainability Pathways Fact sheet. Food and Agriculture Organization of the United Nations, Rome. Retrieved from http://www.fao.org/fileadmin/templates/nr/sustainability_pathways/docs/Factsheet_SMALLHOLDERS.pdf

FAO. (2016). Latin America and Caribbean: Bolivia. Agricultural Development Economics. Food and Agriculture Organization, Rome. Retrieved from http://www.fao.org/economic/esa/esa-activities/esa-smallholders/dataportrait/country-details/en/?cnt=50449

FAO. Tools, Machinery and Equipment. Food and Agriculture Organization of the United Nations, Rome.

Fathallah, F. A., Miller, B. J., \& Miles, J. A. (2008). Low back disorders in agriculture and the role of stooped work: scope, potential interventions, and research needs. Journal of agricultural safety and health, 14(2), 221-245. https://doi.org/10.13031/2013.24352

Friedrich, T., Kienzle, J., \& Kassam, A. H. (2009, November). Conservation agriculture in developing countries: the role of mechanization. In Club of Bologna meeting on Innovation for Sustinable Mechanisation, Hanover, Germany, 2nd November.

Gibson, D. (2014). Methods in comparative plant population ecology. OUP Oxford. https://doi.org/10.1093/acprof:oso/9780199671465.001.0001

Godwin, R. J., Warner, N. L., \& Smith, D. L. O. (1991). The development of a dynamic drop-cone device for the assessment of soil strength and the effects of machinery traffic. Journal of agricultural engineering research, 48, 123-131. https://doi.org/10.1016/0021-8634(91)80009-4

Gould, N. S., Peake, D. C. I., \& Dalgliesh, N. P. (1996). No-tillage seeders for heavy-textured Alfisols in the semi-arid tropics of Australia. Animal Production Science, 36(8), 957-970. https://doi.org/10.1071/EA9960957

Guion, L. A., Diehl, D. C., \& McDonald, D. (2011). Triangulation: Establishing the validity of qualitative studies. Retrieved from http://edis.ifas.ufl.edu/fy394

Gupta, G. R. (2009). When women farm, crops and economies grow. Des Moines Register.

Hanna, M. (2002). Estimating the Field Capacity of Farm Machines. Iowa State University Extension and Outreach. File A3-24. Written April, 2002. Retrieved from https://www.extension.iastate.edu/agdm/crops/html/a3-24.html

Hemken, R. W., Clark, N. A., Goering, H. K., \& Vandersall, J. H. (1971). Nutritive Value of Corn Silage as Influenced by Grain Content 1, 2. Journal of dairy science, 54(3), 383-389. https://doi.org/10.3168/jds.S0022-0302(71)85849-6

Hossain, I. M., Sarker, A. Z., Islam, M. S., Sarker, K. K., Rahman, M., \& Haque, M. E. (2009). Improvement of power tiller operated zero tillage seeder for Upland crops. Annual Report, FMPE, BARI, Jodebpur, Gazipur, Dhaka.

IFAD, U. (2013). Smallholders, food security and the environment. Rome: International Fund for Agricultural Development.

Immink, M. D., \& Alarcón, J. A. (1992). Household food security and crop diversification among smallholder 
farmers in Guatemala. Food Nutrition and Agriculture, (4).

Kienzle, J., Kassam, A., Sims, B., \& Friedrich, T. (2014). Conservation Agriculture: a precision farming tool for smallholders. Proceedings from 6th World Congress on Conservation Agriculture. Winnipeg, Canada. Retrieved from http://www.ctic.org/media/pdf/WCCA/02_Josef\%20Kienzle.pdf

Kottek, M., Grieser J., Beck, C., Rudolf, B., \& Rubel, F. (2006). World Map of the Köppen-Geiger climate classification updated. Meteorol. Z., 15, 259-263.

Lar, M. B., Pour, Z. K., \& Bamimohammadi, G. R. (2011). Field Efficiency and its Use for Energy Coefficient Determination Mansoor Behroozi Lar1, Zahra Khodarahm Pour2, Gholam Reza Bamimohammadi3 1Department of Agricultural Mechanization, Shoushtar Branch, Islamic Azad University, Shoushtar, Iran. behroozil@yahoo. com 2 Department of Agronomy and Plant Breeding, Shoushtar Branch, Islamic Azad University, Shoushtar, Iran. Journal of American Science, 7(8).

Lauer, J., (2002). Agronomy Advice, Methods of Calculating Corn Yield. University of Wisconsin. Retrieved from http://corn.agronomy.wisc.edu/AA/pdfs/A033.pdf

Lazarus, W. F., \& Selley, R. (2002). Farm machinery economic cost estimates for 2002. University of Minnesota Extension Service, College of Agricultural, Food and Environmental Sciences.

Mahmood, T., Ali, R., Iqbal, J., \& Robab, U. (2008). Nitrous oxide emission from an irrigated cotton field under semiarid subtropical conditions. Biology and Fertility of Soils, 44(5), 773-781. https://doi.org/10.1007/s00374-008-0276-4

Migliorati, M. D. A., Scheer, C., Grace, P. R., Rowlings, D. W., Bell, M., \& McGree, J. (2014). Influence of different nitrogen rates and DMPP nitrification inhibitor on annual N $2 \mathrm{O}$ emissions from a subtropical wheat-maize cropping system. Agriculture, Ecosystems \& Environment, 186, 33-43. https://doi.org/10.1016/j.agee.2014.01.016

Mrema, G. C., Baker, D., \& Kahan, D. (2008). Agricultural mechanization in sub-Saharan Africa: time for a new look. Agricultural Management, Marketing and Finance Occasional Paper (FAO). Retrieved from http://agris.fao.org/agris-search/search.do?recordID $=$ XF2009438289

Muth, K. (2011). A Middle-Income Uganda: Aiming For Mediocrity And Failing. London School of Economics, Africa at LSE Retrieved from http://se.ac.uk/africaatlse/2011/07/25/a-middle-income-uganda-aiming-for-mediocrity-and-failing/

Patton, M. Q. (1990). Qualitative evaluation and research methods. SAGE Publications, inc.

Sanchez, P. A., Shepherd, K. D., Soule, M. J., Place, F. M., Buresh, R. J., ... Woomer, P. L. (1997). Soil fertility replenishment in Africa: an investment in natural resource capital. Replenishing soil fertility in Africa, (replenishingsoi), 1-46.

Shaw, R. P. (2015). Mobilizing Human Resources in the Arab World (RLE Economy of Middle East). Routledge, 64.

Smithers, J., Lagrange, L., Fraser, B., Neethling, D., \& Hill, A. (2010). Design and evaluation of a jab seeder.

Thiagalingam, K., McNamara, T., \& Gould, N. S. (1991). No-till technology and legume rotation for sustainable crop production in the Douglas Daly region of the Northern Territory, Australia. Soil and Tillage Research, 20(2-4), 285-292. http://doi.org/10.1016/0167-1987(91)90044-X

Thierfelder, C., \& Wall, P. C. (2009). Effects of conservation agriculture techniques on infiltration and soil water content in Zambia and Zimbabwe.Soil and tillage research, 105(2), $217-227$. https://doi.org/10.1016/j.still.2009.07.007

Tyler, D., Overton, J. and Chambers, A. (1983) Tillage effects on soil properties, diseases, cyst nematodes, and soybean yields. Journal of Soil and Water Conservation, 38, 374-376.

USDA NRCS. (2004). $3.3 \quad$ Bulk Density. Retrieved from http://www.nrcs.usda.gov/Internet/FSE_DOCUMENTS/nrcs142p2_051670.pdf

Vanderwal, L., Rautiainen, R., Kuye, R., Peek-Asa, C., Cook, T., Ramirez, M., ... Donham, K. (2011). Evaluation of long-and short-handled hand hoes for land preparation, developed in a participatory manner among women vegetable farmers in The Gambia. Applied ergonomics, 42(5), 749-756. https://doi.org/10.1016/j.apergo.2010.12.002

Wolfenson, K. D. M., \& Rome, A. (2013). Coping with the food and agriculture challenge: smallholders' agenda. 
Wollenhaupt, N. C., \& Pingry, J. (1991). "Estimating residue using the line-transect method." Technical rep., A3533, Univ. WisconsinExtension, College of Agriculture and Life Sciences, Madison, WI.

World Census of Agriculture Database. (2010). Food and Agriculture Organization, Rome. Accessed February, 2016.

Yin, X., McClure, M. A., Jaja, N., Tyler, D. D., \& Hayes, R. M. (2011): In-Season Prediction of Corn Yield Using Plant Height under Major Production Systems. Agronomy Journal, 103, 923-929. https://doi.org/10.2134/agronj2010.0450

\section{Notes}

Note 1. March, 2016 issue of Crops, Soils, Agronomy featured a front page article on one of the seeders in this study, the Greenseeder, and discusses this research by Harman et al. ("Greenseeder: Hand planter could boost productivity for world's poorest farmers")

Note 2. Reported farm size in SSA is 1.3 ha, Near East and North Africa is 4.2 ha, Asia is 1.06 ha, Pacific is 5.8 ha, Central America and the Caribbean is 22.2 ha, South America is 50.7 ha and all developing countries is an average of 2.7 ha (IFAD, 2013; UNEP; FAO, World Census of Agriculture Database (accessed February 2016), $\mathrm{UN}$ (2007).

\section{Copyrights}

Copyright for this article is retained by the author(s), with first publication rights granted to the journal.

This is an open-access article distributed under the terms and conditions of the Creative Commons Attribution license (http://creativecommons.org/licenses/by/4.0/). 